\title{
Rhetorical criticism and the hermeneutics of the New Testament
}

Elma M. Cornelius

School for Biblical Sciences \& Bible Languages

Potchefstroom University for CHE

POTCHEFSTROOM

E-mail: klsemc@puknet.puk.ac.za

\begin{abstract}
Rhetorical criticism and the hermeneutics of the New Testament

It is argued that rhetorical criticism is increasingly recognized as a method of interpretation of biblical literature. From the discussion in this article it becomes clear that there are different perspectives of rhetorical criticism just as there are different theories of rhetoric. It is argued that contemporary critics need to develop an interdisciplinary method of rhetorical criticism in order to answer questions about the potential effectiveness of a rhetorical act. It is concluded that the rhetorical critic needs a combination of "old" methods in order to answer new questions.
\end{abstract}

\section{Introduction}

Burke's book (1950) specifically deals with the question where rhetorical criticism is taking us. Wuellner (1987:462) answers this question with: "it takes us to interdisciplinary studies ... (it) approaches all literature".

When interpretations of the New Testament are studied - especially the use of rhetorical criticism for New Testament interpretation, it becomes clear that confusion exists about the concepts "rhetoric", "rhetorical theory" and "rhetorical criticism". In some cases writers use the word "rhetoric" as a synonym for "rhetorical theory" or sometimes "rhetorical criticism". Thuren (1990:43) for example, in discussing the nature of rhetorical criticism, states that "rhetorics seeks to study what is the purpose of any discourse ...". He, however, continues that "rhetorics analyzes the means utilized in a text ..." (Thuren, 1990:43). He also describes rhetorics as "a method of practical criticism", when he discusses modern conceptions of rhetorics (Thuren, 1990:52). These quotations serve to demonstrate the confusion in this regard. To avoid any misunderstanding in this article, I will first distinguish between the following concepts: 
- rhetoric and its relation to "communication" and epistolography";

- rhetorical act and artefact;

- a theory of rhetoric; and

- rhetoric and its relation to "communication" and "epistolography";

- rhetorical criticism.

\subsection{Rhetoric and its relation to "communication" and "epistolography"}

Aristotle (Ars Rhetorica I:ii,1) and Quintilian (Institutio Oratoria II:15-21) define rhetoric respectively as follows:

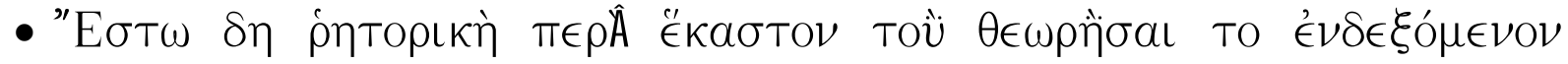
$\pi \iota \theta \alpha \nu o ́ v$. (Rhetoric, then, may be defined as the faculty of discovering the possible means of persuasion in reference to any subject.)

- Scientia bene dicendi. (Rhetoric is the science/knowledge of eloquence/speaking well.)

Rhetoric is often seen as part of modern theories of argumentation (Van Eemeren et al., 1987:55-107). Others consider it to be the art of persuasion (Miller et al., 1984:400-403). Thuren (1990:58) agrees with the latter definition, except that he adds that it is the art of persuasion "in general". Foss (1989:4) defines rhetoric as "the use of symbols to influence thought and action; it is simply an old term for what is now commonly called communication". Kennedy (1992:2) argues that rhetoric should not be identified with communication, since there seem to be various degrees of rhetoric among kinds of communication. Kennedy explains that "zero grade" rhetoric, for example, may be approached but never quite achieved. Rhetoric in the most general sense, he says, may perhaps be identified with the energy inherent in communication. Communication involves emotional energy that impels the speaker to speak, and implies physical energy expended in the utterance, the energy level coded in the message, and the energy experienced by the recipient in decoding the message. The point is that a form of communication may be a zero grade rhetoric, and there may be various degrees of rhetoric among kinds of communication, but it is still "rhetoric". Any form of communication is an attempt to bring about changes in, or a strengthening of people's thoughts, words, attitudes, emotions or actions. I therefore persist in identifying rhetoric with "communication".

When classical theoreticians of both disciplines are consulted about the relationship between rhetoric and epistolography, it transpires that confusion exists (see the survey of Cornelius, 1991:18-30). The whole 
debate, Watson and Hauser (1994:121) says, is based in part upon the fact that epistolary theory and rhetorical theory were developed separately in antiquity. Epistolary theory in antiquity belonged to the domain of the rhetoricians, but it was not originally part of their theoretical systems.

Murphy (1974) makes a valuable contribution in this regard with his Rhetoric in the Middle Ages. He (1974:202-203) is of the opinion that the existence of the ars dictaminis can be linked with the Benedictine monastery of Monte Cassino in central Italy. According to Murphy, a monk with the name Alberic was the first to link rhetoric and epistolography in a formal treatise round about 1087. Alberic gave an application of the rhetorical principles to the practice of letter-writing (Alberic Dictaminum radii and Brevarium de dictamine). From this it appears that even Alberic could not succeed in distinguishing between the formal categories of ancient rhetoric and epistolography. He considered for example the "letter-greeting" (an epistolary form) as the first part of the letter and the exordium, narratio, argumentatio and conclusio (rhetorical forms) as the ensuing parts. Thus he does not consider the first epistolary form (the letter-greeting) as part of the first rhetorical form (the exordium).

Murphy (1974:194-268) considers the ars dictaminis as "a sharp break with the ancient rhetorical practice", but also as "a rare example of applied rhetoric". He summarizes the relationship between the two disciplines very well when he says that "eloquent letters, like eloquent speeches, were expected to be the product of broad rhetorical education" (Murphy, 1974:195).

In the research tradition, one can identify three different approaches to the interpretation of New Testament letters:

- Some theoreticians interpret letters only in terms of epistolographical categories (see for example White, 1972; 1984).

- Theoreticians like Berger (1974), Kraftchick (1985) and Johanson (1987) interpret letters with an approach in which rhetoric plays a more important role than epistolography.

- Others, like Wuellner (1976) and Stowers (1986), try to use both rhetoric and epistolography to the same degree in the interpretation of letters.

From these different approaches it is clear that the relationship between rhetoric and epistolography is an actual problem, especially in the development of a method of interpretation of New Testament letters. 
Thuren (1990:58) correctly summarizes this problem when he says that the dilemma of divergent opinions on the relationship between ancient rhetoric and epistolography is mostly due to different views of rhetoric. If "rhetoric" is seen narrowly as a study of the conventions of a speech, the first and second possibilities above will be considered. Thuren, however, chooses the third possibility because he argues that rhetoric should be perceived on a higher level than the art of persuasion in general.

Vorster (1991:76) is of the opinion that a letter should be seen as part of the rhetorical act and that all the elements of a letter are rhetorical. According to him (1991:75-76) letter-writing is a species of the genus rhetoric. In the interpretation of letters it must thus be an ideal not to work only formally epistolographically, but to analyze the rhetorical situation as well. Botha (1994:140) concludes by saying that, from the discussion of the relationship between rhetoric and epistolography, it is clear how important it is not to confine one's conception of rhetoric to classical rhetoric alone, but to work with the broader perspective proposed by modern rhetoric.

\subsection{Rhetorical act and artefact}

Campbell (1982:6) defines the "rhetorical act" as an intentional, created, polished attempt to overcome the obstacles in a given situation with a specific audience on a given issue to achieve a particular end. Foss (1989:5) differentiates between "rhetorical act" and "artefact". The rhetorical act is executed in the presence of the rhetor's intended audience. The artefact is the trace or tangible evidence of a rhetorical act.

\subsection{Theory of rhetoric}

Croft (1965:414) defines rhetorical theory as a basis for criticism which should consist of a series of formal techniques drawn from the history of rhetorical theory and unified into a general system. A theory of rhetoric states the basic facts, central laws, and fundamental components of the rhetorical process. The theory describes how rhetoric operates in human communication (Johannesen, 1971:2). Brinton (1981:239) says it is the normative theory of fitting response to certain kinds of situations - it provides the basis for rhetorical criticism. Any critic has to spell out his or her theory of rhetoric, which is a theoretical framework for the way in which rhetoric can be conceptualised for the purpose of rhetorical criticism, and an explanation of one's view of the rules and means of effective communication. 
It is important to realize that a single, unified, complete, generally accepted body of precepts for rhetorical theory is an impossibility (see Winterowd, 1968:77-78). It is, however, essential to spell out the particular theory of rhetoric which I presuppose in my interpretation and evaluation of the effectiveness of the rhetorical act. It is important to indicate what I consider effective communication to be, as no unified theory of rhetoric exists.

Choosing an appropriate theory is not an easy task. We are mainly confronted by two groups of theories: traditional (also called classical) and the so-called "new rhetoric". The classical theory of rhetoric, for the first time systematically recorded in Aristotle's Ars Rhetorica, is the only systematized system available. The "new rhetoric" is a concept used by various authors, but none of these authors interprets this concept in the same way. There is, however, one resemblance, namely that all the representatives of the "new rhetoric" attempt to break away from the traditional theory (see for example Simons, 1971; Ohmann, 1971; Perelman \& Olbrechts-Tyteca, 1969). Hochmuth Nichols (1971a and $1971 \mathrm{~b})$ also classifies Burke and Richards as representatives of this "new rhetoric". But still there is no single theory of the "new rhetoric".

Croft (1965:407) is of the opinion that the forms or techniques of an art are of no value in themselves to a critic, but that they are only tools with which to pry into a specimen of the art. Criticism does not consist of finding illustrations of standard, preconceived forms. The critic must use the frameworks of standard techniques and strategies as norms to help him or her discover and evaluate the ways in which the speaker's use of these techniques and strategies for example is distinctive. The theory of rhetoric is thus used for practising rhetorical criticism.

\subsection{Rhetorical criticism}

Hughes (1989:23) acknowledges that rhetorical criticism is becoming more and more recognized as a method of interpretation of Pauline as well as other biblical literature. Rhetorical criticism is more than mere stylistic analyses, social descriptions or historical reconstructions (see Wuellner, 1995:161). Andrews (1990:3) considers rhetorical criticism to be the process of focusing attention on human efforts to be persuasive. To be more specific, rhetorical criticism regards a speech as an act of communication with a specific audience, and mainly concern the analysis and appreciation of the orator's method of imparting his or her ideas to the hearers (Andrews, 1990:6). Foss (1989:5) considers rhetorical criticism to be the investigation and evaluation of rhetorical acts and artefacts for the purpose of understanding rhetorical processes. A critic, Richards (1954:180) says, must first discern what meanings are being 
communicated, and thereafter, how successfully these are being communicated. What is common to all these definitions is that rhetorical criticism concerns the interpretation and evaluation of a specific act of communication. This definition is closely related to the objectives of rhetorical criticism.

\section{Objectives of rhetorical criticism}

The primary purposes of rhetorical criticism are to describe or analyse, interpret, and evaluate a rhetorical act (Scott \& Brock, 1972:9; Campbell, 1982:16; Andrews, 1990:6). The central objective of critical research, Croft (1965:411) says, is evaluation. Thonssen et al. (1970:19) elaborates this view by saying that rhetorical criticism seeks an answer to the question to what extent, and through what resources of rhetorical craftmanship, has the speaker achieved the end. One can summarize this view by saying that the purpose of rhetorical criticism is a determination of the communicative functions of a text and the evaluation of the probable effectiveness of a text.

Audience adaptation is very important in this kind of study (Croft, 1965: 408). A very important function of rhetorical criticism is to show how propositions and audiences are connected; how speakers use techniques and strategies to adapt their ideas to the ideas of their audiences. The flaw in many aspects of modern rhetorical criticism, Croft (1965: 408) says, has not been that it ignored this necessity, but rather that it has devised inadequate tools to deal with it. Audience adaptation is a job of being aware of societal and cultural predispositions as premises in arguments, of fitting the speaker's basic social values to those of the listeners, of taking into account the cultural myths or images to which the audience responds as well as the nonverbal cues to which the audience reacts - such as artifacts and space (see Larson, 1998:210-233).

Croft (1965:409) identifies the following objectives of rhetorical criticism:

- The historical function: to report and interpret the manner in which a speaker's social values have been related to the social values of his or her audience in the course of his or her rhetorical adaptation.

- The evaluative function: to evaluate the effectiveness of the rhetorical act by estimating the appropriateness and evaluating the uniqueness of the idea-adaptation.

- The creative function: to re-examine, re-evaluate, and if possible to modify contemporary rhetorical theory through the examination of the adaptive processes. 
The creative function seems to be the conclusive function of rhetorical criticism - the last step in which the rhetorical critic concludes his or her study by re-evaluating rhetorical theory. It could, for example, be possible to say that, from the specific study, it became clear that communication took place in a different way from what has actually been assumed. This study can also, for example, end with the realization that Paul communicated in a different way from that prescribed by the rules of classical rhetoric. And that may be the starting point of a new rhetorical theory, specifically concerning Paul's communication in the New Testament.

It is a challenge to try not only to describe and interpret, but also to evaluate the probable effectiveness of a rhetorical act. To determine effect, however, is not just finding out what happened after the act of communication; it is a careful examination of the interrelationships between text and context in order to offer the most reasonable explanation for the probable result of any given message (see Andrews, 1990:8). But, as I have already mentioned, up till now inadequate tools have been devised to deal with the particular function of evaluation. Therefore it is necessary to consider a number of the available methods of rhetorical criticism.

\section{Methods of rhetorical criticism}

To describe "the" method of rhetorical criticism is an impossible task. The development of methods of rhetorical criticism is influenced by the development of rhetorical theories. Cohen (1994:69) observes that the past three decades have witnessed a remarkable resurgence of interest in rhetorical theory. This interest, however, has taken a number of distinct forms. Mack (1990:19) acknowledges that there is no single network of scholars exchanging ideas about rhetorical criticism - no school, acknowledged master, or canon of methods. "Some theorists", Cohen (1994:69) says, "have sought to extend the traditional understanding of rhetoric as a methodology for the study of argument". Others have paid little heed to rhetoric's historical parameters since they have reconceptualized rhetoric as the analysis of fictional narrative. Still others have attempted to overcome the ancient antagonism between philosophy and rhetoric by construing rhetoric as the framework for a philosophy of discourse. Finally, "post-modernist thinkers have turned to rhetoric precisely because of its repudiation of philosophical conceptions of knowledge and truth" (Cohen, 1994:69).

Scott and Brock (1972) identify the different trends within the frame of rhetorical criticism as the traditional perspective, the experiential perspective, and the "new rhetoric". In the third revised edition of this book 
(Brock et al., 1990) the perspective of the "new rhetoric" was replaced by a discussion of the dramaturgical perspective, and they also added the sociological perspective and the postmodern perspective. In the next section I will briefly summarize both discussions of the various trends in rhetorical criticism. I do this in order to indicate that the various trends in rhetorical criticism are closely linked to different underlying theories of rhetoric.

\subsection{The traditional perspective}

Within the traditional perspective, the critic concentrates on the speaker to consider the speaker's response to the rhetorical problems that the speaking situation poses. The classical system of rhetoric is used as rhetorical theory and the different rhetorical strategies are studied. With the use of the classical rhetorical theory, rhetoricians generally agree on what the ideal rhetorical process is, and the critic makes the following assumptions:

- Society is stable; people, circumstances, and rhetorical principles are fundamentally the same throughout history.

- Rhetoricians have discovered the essential principles of public discourse.

- Rhetorical concepts are reasonably discrete and can be studied separately in the process of analyzing rhetorical discourse.

- A reasonably close word-thought-thing relationship exists. Rhetorical concepts accurately describe an assumed reality.

\subsection{The experiential perspective}

For critics working from this perspective, no single element or rhetorical principle can be assumed as the starting point for criticism. The critic must make the fundamental choice. The critic believes that no special pattern exists for the study of public discourse. Discourse must continually be studied anew. No specific method is used and the critic makes the following assumptions:

- Society is in a continuous process of change.

- An infinite combination of concepts, strategies, and principles are available for the study of public discourse.

- Any system of categorizing is arbitrary and does not accurately reflect an assumed external reality for extended periods of time. 


\subsection{The perspective of the "new rhetoric"}

According to the perspective of "new rhetoric", rhetorical criticism must find a starting point in the interaction of humans and their social environment. The perspective of the "new rhetoric" can be divided into different approaches.

The semantic-grammatical and dramatistic approaches are examples of the "new rhetoric". In these approaches we find, for example, textual analyses and analyses of motives. All "new rhetoric"-critics, however, agree that a unified rhetorical framework is necessary for productive rhetorical criticism. The following assumptions are made:

- Society is in a process of change, but fairly stable relationships can be found that govern the interaction of humans with their environment.

- A flexible framework may be constructed for the study of public discourse.

- People's symbol systems influence their perceptions of reality.

\subsection{The sociological perspective}

For rhetorical critics employing the sociological perspective, society and communication are intimately related forces that mutually define each other. The structure, institutions, and processes of society and communicative exchanges are viewed as continuously interacting and mutually defining systems. A wide diversity of theories is likely to emerge from this perspective of rhetorical criticism.

The four major approaches to rhetorical criticism that can reasonably be viewed as related extensions of a sociological worldview, include the "sociolinguistic", "generic", "social movements", and "feminist" approaches. The following assumptions are made:

- Societies develop built-in adjustment and control mechanisms that minimize change and promote stability and inertia.

- The values and consensus mechanisms of societies establish the parameters for the study of communication.

- The symbolic frameworks unifying and regulating society determine the psychology of individuals and the range of feasible rhetorical options available to individuals in rhetorical situations.

- The word-thought-thing relationship is directly regulated by the structure, institutions, and processes of society. 


\subsection{The postmodern perspective}

The purpose of the postmodern critic is to identify how power texts construct social realities and in their turn can be deconstructed. Postmodern criticism is essentially antitheoretical. Of these approaches the constructionist and deconstructionist approaches are examples. The following assumptions are made:

- The modern industrial state creates, maintains, and uses a series of paradoxical symbolic constructions of reality as modes of social control.

- To understand the control systems employed by societal systems, the diverse symbolic constructions of reality must be identified by the rhetorical critic.

- In order to promote equality, the rhetorical critic functions as a social activist, deconstructing the symbolic constructions of reality erected by political elites.

- The word-thought-thing relationship is directly challenged by postmodern critics. The word-thought-thing relationship is cast as solely arbitrary and conventional, designed to create and reinforce wordthought relationships that facilitate dominant and subordinate relationships.

Watson and Hauser (1994:115) summarizes this process as follows: "Rhetorical analysis using modern rhetoric is often combined with literary criticism, text linguistics, semiotics, social description, stylistics, readerresponse criticism, discourse analysis, and/or speech act theory". And they then acknowledge that these cross-disciplinary studies and their trends are difficult to identify and categorize.

From this summary, it is clear that there are different perspectives of rhetorical criticism just as there are different theories of rhetoric. Attention has been given to the assumptions underlying each perspective which are closely connected with the philosophical presuppositions of each perspective. But still, it has not been spelled out how rhetorical criticism should be done. Rhetorical critics usually limit themselves to descriptions of typical strategies used in communication, while one hardly finds an evaluation of the probable rhetorical effectiveness of the rhetorical act. Clearly there are serious problems with rhetorical criticism. Rhetorical criticism, understood as interpretation and evaluation, remains a vague concept. In the next section I will briefly review and criticize various proposals for a suitable approach to rhetorical criticism. 


\section{Problems of a method of rhetorical criticism}

With regard to rhetorical critical studies in the field of biblical interpretation, Vorster $(1991: 22,35)$ distinguishes between rhetorical studies before 1975 and after 1975. Those before 1975 (and some of these even proceeded after the attempts of Betz [1975] and Wuellner [1976]) are mere ornamental or elocutional rhetorical criticism, while Wuellner (1976) advocated a departure from elocutional rhetorical criticism to argumentative analysis. "Rhetorical criticism as exegetical activity within New Testament studies", Vorster (1991:22) says, "developed from problems posed by epistolographical studies". Because epistolographical studies are mainly concerned with the structure of the letter, the problems posed by epistolography are therefore structurally related. "Structure" plays a very important role in the work done by New Testament rhetorical critics. This can be seen in the attempts to prove the relationship between various textual parts.

Croft (1965:406) describes the situation of rhetorical criticism as follows:

... a researcher takes the old theory, finds illustrations of it, piles these up, and concludes, for example, that a given man's speaking exhibits characteristics which may be said to fall properly within the categories of traditional rhetoric.

"This sort of criticism," he says, "works upon the presumption that rhetoric is rhetoric, and, beyond deciding which traditional doctrine he prefers, the critic shall not fancy himself a creative theorist." "And so," Croft concludes, "we have made rhetorical criticism a dead-end street". Croft $(1965: 406)$ is of the opinion that the standard forms in rhetorical criticism in the field of speech treat traditional theory as a closed, fixed system and that very little effort is made to evaluate the rhetorical act no critical conclusions are drawn. This approach, he says, cannot be called criticism in the sense of evaluation. Croft (1965: 406) encourages creative theorizing as a part of criticism.

Wuellner (1987:451) is of the opinion that rhetoric has been restricted, distorted and paralysed throughout history, while biblical exegetes remained unaware of it. He identifies two fragments of rhetorical criticism from Augustine in the fourth century to Eagleton in the twentieth century: Augustine views rhetorical analysis as synonymous with literary criticism (with the emphasis on stylistics), while Eagleton views it as synonymous with practical criticism (Wuellner, 1987:450-453).

Muilenburg (1969) made rhetorical criticism fashionable again with his Presidential Address at the Society of Biblical Literature entitled "Form Criticism and Beyond". Even so, Wuellner (1987:451) claims that the 
Muilenburg school still did not succeed in developing an identifiable model. Black (1989:254) suspects that Muilenburg's definition of rhetoric is too narrow because his method focuses upon the literary features of texts.

Muilenburg probably considered "rhetoric" to be "literary artistry". Black (1989:253) describes the Muilenburg method as exhibiting the structural patterns that are employed for the fashioning of a literary unit and discerning the many and various devices by which the predications are formulated and ordered into a unified whole. Black (1989:253) is, however, of the opinion that with his definition and execution of rhetorical criticism, Muilenburg was the most influential figure in Old Testament rhetorical criticism. For most Old Testament scholars "rhetorical criticism" meant what Muilenburg proposed, namely the study of a particular text in its present form, separate from its generic rootage, social usage, or historical development. It thus seems as if Muilenburg was responsible for a change in Old Testament interpretation to rhetorical criticism, but he did not succeed in defining a clear method. The greatest merit of his work was that he pointed to a challenging task (Kessler, 1982:5).

In 1977, Kikawada (1977:67-91) also called for a method of rhetorical criticism. During the past twenty years, alternative methods have indeed been developed. And if one wants to study the different methods, it is of great help to start with the methods used by those who are considered to be the "leaders" - who made the most important contributions. Wuellner (1987:453-454) is of the opinion that Perelman (1982) and Kennedy (1984) have turned rhetorical criticism around.

Kennedy's model of rhetorical criticism (1984) was in a way an answer to the need for renewed interest in rhetoric. He also paid attention to other researchers' interest in the development of rhetoric. Kennedy (1984:314) considers "rhetoric" as "the art of persuasion", as practised by the ancient Greeks and Romans. Based on the precepts of ancient classical theorists, Kennedy (1984:33-38) proposes the following method of rhetorical criticism:

- Determine the rhetorical unit.

- Define the rhetorical situation.

- Identify the rhetorical problem.

- Examine the arrangement of the parts into a unified discourse.

- Analyse each part for its invention and style.

- Evaluate the rhetorical effectiveness of the unit.

Black (1989:255) is of the opinion that Kennedy's primary contribution is methodological: the presentation of a distinctive method of rhetorical 
criticism that is lucid and systematic. Kennedy's approach to a text is purely rhetorical.

He approaches a letter as an argument, considers the methods of persuasion in the various parts of the argument, and determines their functions. His analysis of the rhetorical situation entails mainly two aspects: the audience, and the rhetorical problem faced by the speaker (Kennedy, 1984:25, 36). Kennedy, therefore, intends to explain the form of communication by means of the "rhetorical situation". Even so, he confuses his categories again when he inquires about the author's intention $(1984: 4,12)$ which is part of the "historical situation".

According to Kennedy (1984:34), this concept of "author's intention" more or less corresponds to the Sitz im Leben. The rhetorical critic, he says (1984:4), takes the text as it is, and considers it from the perspective of the author's intention, as well as the way in which it would have been received by a contemporary audience. When Kennedy distinguishes between rhetorical and literary criticism (1984:4-5), he explains that literary criticism investigates the reception of a text by modern audiences, while he himself endeavours to read the text in the same way as it would have been read by its first readers. Thuren (1990:68) says that Kennedy (1984) employs rhetoric as an ancient version of literary criticism. Kennedy's model is based completely on the ancient rhetorical system, which he uses both formally and functionally.

The sixth step in Kennedy's method, namely to evaluate the rhetorical effectiveness of the rhetorical unit, seems to remain only one step in the whole process. In Kennedy's (1984:141-144) interpretation of 1 Thessalonians, he never comes to an evaluation of the possible success of the rhetorical act constituted by this letter. A clearer method of rhetorical criticism is therefore no guarantee for writing good criticism. It seems as though the last step of evaluation remains a vague concept.

Wuellner (1987:461) says that “... rhetorical criticism leads us away from a traditional message- or content-oriented reading of Scripture to a reading which generates and strengthens ever-deepening personal, social and cultural values" and he regards Perelman as the scholar who brought about radical changes in rhetorical criticism. Arnold, who translated Perelman's work (1982), notes in the introduction of this book (1982:xvii) that the broad conception of rhetoric, as presented by Perelman, primarily originated in the USA, where students in literary prose were responsible for its rebirth. According to Arnold, Baldwin's work, Rhetoric in Monroe's Cyclopaedia (1914), emphasized the fact that rhetoric is more than stylistics. At the same time, a group of rhetoricians, and literary and classical scholars, referred to as the Cornell University 
School, focused their research on the study of the theory and praxis of ancient rhetoric. Since 1914, the Speech Communication Association has emphasized the importance of practising rhetorical criticism from a variety of disciplines. These studies were conducted in a number of disciplines, including psychology and historical criticism. Starting with Perelman, philosophy received more and more emphasis. Arnold (in the introduction of Perelman, 1982:xix) indicates that Perelman writes as a philosopher. Perelman analyses the logic of arguments in a philosophical way and he can thus be regarded as a rhetorical critic working from a philosophical perspective.

The new rhetoric, presented by Perelman (1982), entails communication directed at all kinds of audiences on any topic. The general study of argumentation should, according to Perelman (1982:5), be supported by various disciplines that might be valuable. He does take note of the ancient rhetorical system (1982:6), but also transcends it.

In 1987 Schussler Fiorenza (1987:386) identified the need for an "integrative" paradigm for rhetorical criticism. This new paradigm requires a balance between the historical approach and literary criticism and sociological approaches to New Testament exegesis. Her work presents an important indicator for the future direction of rhetorical criticism, and it also emphasizes the importance of interdisciplinary studies.

Thuren (1990:42) defines rhetorical criticism as a "general approach". He says that rhetorical criticism in the field of biblical exegesis is not yet based on a unified view of rhetoric (Thuren, 1990:45). Some scholars apply ancient rhetoric, while others use modern linguistics, still others work with rhetoric, but they use new terminologies and concepts. His own method of rhetorical criticism is closely related to that of Kennedy (1984), and comprises the following:

- identification of the rhetorical unit;

- identification of the rhetorical situation;

- study of the order; and

- analysis of stylistic elements.

With these four steps, Thuren makes full use of the ancient rhetorical system, both in the formal and in the communicative-functional sense. The same critique can, however, be applied to Thuren as to Kennedy. An evaluation of the probable effectiveness of a rhetorical act in its original rhetorical situation does not occur.

Wuellner (1987:449) makes good use of Perelman's model and indicates that rhetorical criticism brings us to a greater harvest - a harvest of new 
attempts made in various fields of rhetoric. Rhetorical criticism goes further than the view of language as a reflection of reality. It takes us to the social aspects of language as an instrument of communication, an instrument with the potential to influence people.

Black (1989:256) is of the opinion that in most rhetorical critical studies, with the exception of Kennedy's (1984), the interpretative tactics and exegetical implications have not yet come completely into focus. The question remains whether Kennedy really succeeded in doing what he had in mind in the last step of his rhetorical criticism, namely the "evaluation." Most of the work that has been done on Paul in the name of rhetorical criticism, Wuellner (1987:455) says, falls short in his (that is Wuellner's) view.

For Vorster (1991:23) rhetorical criticism is concerned with the question of why an argument could be deemed appropriate within a certain context. It is concerned with pragmatics. He (1991:39) typifies his work as an "interactional analysis" and uses an "interactional model". He further acknowledges that to a certain extent he has adopted an eclectic and pragmatic approach because he has used elements from various models and adapted where necessary. To establish the purpose of the letter to the Romans, he restricts the field of study to the framework of the letter, especially the beginning and end of the letter (1:1-17 and 15:716:23). He uses insights from reader-oriented disciplines such as pragmatics, reception-criticism and rhetoric. Vorster definitely brought new insights concerning the purpose of the letter to the Romans. Methodologically he introduced us to the value of pragmatics. This study, however, also does not provide us with a method of rhetorical criticism, specifically when it comes to the evaluation of the probable effectiveness of a rhetorical act.

Robbins (1996a and 1996b) calls his method of biblical interpretation "socio-rhetorical criticism". With this method he approaches a text as a thick tapestry, seen from different angles in order to grasp different configurations, patterns and images. "When we explore a text from different angles", he says, "we see multiple textures of meanings, convictions, beliefs, values, emotions and actions" (Robbins, 1996a:18). He describes four arenas of texture: inner texture, intertexture, social and cultural texture and ideological texture (Robbins, 1996a). And then in another book he adds the sacred texture (Robbins, 1996b).

- Inner texture, he (1996b:3) says, concerns features like the repetition of particular words, the creation of beginnings and endings, alternation of speech and storytelling, particular ways in which the words present arguments, and the particular "feel" or aesthetic of the text. 
- Intertexture concerns a text's configuration of phenomena that lie outside the text. Examples of such texture are social intertexture such as the structure of families, political arrangements, and cultural intertexture such as the ideas of people about their responsibilities in the world, and historical intertexture such as events which occur outside the text.

- Social and cultural texture concerns the capacities of the text to support social reform, withdrawal, or opposition and to evoke cultural perceptions of dominance, subordinance, difference, or exclusion.

- Ideological texture concerns the way the text itself and interpreters of the text position themselves in relation to other individuals and groups.

- Sacred texture exists in the texts that somehow address the relation of humans to the divine and exists in communication about gods, holy persons, spiritual beings, divine history, human redemption, human commitment, religious community, and ethics. Robbins focused our attention on the multiple textures of a text and the necessity of various disciplines to interpret such a text. His method is also a very thorough way of interpretation. But I still miss the issue of evaluation of the probable effectiveness of the rhetorical act in his method.

Scott and Brock (1972:404) conclude their study by saying that we should expect, at the very least, a lessening of interest in theorizing about rhetorical criticism and a revitalized concern with criticizing public discourse. During the past twenty five years, however, this still has not happened. In connection with this, Andrews (1990:62) states that it is most important that a practising rhetorical critic does criticism. We have to realize that the ideal of a "unified view" of rhetorical criticism will remain an ideal. Rhetoric is much too complex a concept to capture in one single system. For much too long researchers on the New Testament have been quarrelling about the proper method of rhetorical criticism. Knowledge about what rhetorical criticism is, does not automatically translate into the ability to do criticism (Foss, 1989:11). The goal of rhetorical criticism, Andrews (1990:62) says, must be to write good criticism, and good criticism is that which ultimately promotes a richer understanding of the influence and operation of discourse and contributes to the comprehension and refinement of humane values. The complex of interactions that take place between a speaker and his or her audience is never easy to understand fully indeed; total comprehension of any rhetorical exchange is not to be obtained (Andrews, 1990:61), but the critic, nevertheless, should strive to come as close to the achieve- 
ment of that goal as he can to contribute to the ongoing work of other rhetorical scholars.

In this section I have tried to give an overview of the problems regarding a method of rhetorical criticism in general.

\section{Choosing or developing a method of rhetorical criticism}

Foss (1989:17) gives three possibilities when selecting a method:

- use an existing critical method;

- create a method from an existing concept; and

- create a new method.

Many critics have already done rhetorical critical studies of the New Testament. As I have already indicated, there does not exist only one method for rhetorical criticism. In so far as rhetorical criticism concerns description and interpretation of typical persuasion strategies, to find a method is no problem at all as there are many different methods and strategies to explore the different textures of discourse. But in the case of an evaluation of the probable effectiveness of the rhetorical act, "method" is an issue. Although there are various expositions of possible approaches to rhetorical criticism available today, nobody has spelled out a clear method for the evaluation of the probable effectiveness of the rhetorical act as an integral part of rhetorical criticism.

According to Andrews (1990:5) any rhetorical critic has one or both of the following tasks: to answer questions about the rhetorical message or to develop a methodical way of answering those questions. The best way to interpret a text would be to investigate all three main elements in the process of communication, namely the author, text and readers. Such an attempt, although not an easy one, can open up new perspectives and make possible the consideration of old issues, although on a different level. The question, however, is - will such a design of a paradigm not end up in eclecticism? Kael (1964:309) answers this question as follows: "eclecticism is the selection of the best standards and principles from various systems of ideas ... it requires more orderliness to be a pluralist than to apply a single theory". Campbell (1982:5) agrees that a rhetorical perspective is eclectic and inclusive in its search for what is influential and why. A method of rhetorical criticism is the use of a combination of existing and "old" methods in order to answer new questions.

The challenge for any critic is to use a method which has the potential to answer questions about the probable effectiveness of the rhetorical act represented by the artefact. An adequate rhetorical analysis of an 
ancient document is according to me an analysis that is thorough, consistent, taking cognizance of ancient theory, and providing the analytical tools for an eventual evaluation of the probable effectiveness of the rhetorical act constituted by the artefact.

The question, however, remains how to determine effectiveness. Bettinghaus and Cody (1994:6) are of the opinion that the effects of an act of communication are determined by the change in (or strengthening of) behaviour, cognition and affect. They present four criteria to be considered in judging the effects of persuasive communication, namely the nature of the correspondence between the intentions of the participants, the degree of correspondence between the intentions of the source and the subsequent behaviour of the receiver, the nature of the opposition to be expected to the communicator's position, and the difficulty level of the task being engaged in (Bettinghaus \& Cody, 1994:16-17). In the interpretation of New Testament texts, it is impossible to determine to what degree there has been a change in or strengthening of the first readers' concepts, beliefs, values and perceptions. It is also impossible to determine whether there was indeed a change in, or strengthening of the readers' emotional states, their actions, thoughts and words. It is, however, possible to determine the "probable" effectiveness of the New Testament by asking the following questions:

- Is the author's creation and presentation of the "truth" similar to what the readers will accept and acknowledge to be the "truth"? If it is not similar, the effectiveness of the text will probably decrease.

- Does the author attempt to arouse in the minds of his readers as clear, accurate, and complete a picture or conception of his subject as possible? If the readers have a blurred image of the subject, the effectiveness of the act will be influenced.

- Are relevant aspects provided by the text to inform the readers in order to respond constructively to the purpose of the text? If not, readers may not respond effectively.

- How does the pattern of the argument in the letter contribute to the clarity of the author's intentions and subject?

- How creatively does the author respond to the obstacles faced with regard to his creation of an environment of socialization, his creation of the attributes and roleplay of the participants in the socialization process, his use of persuasion strategies, style, and epistolary conventions? All these aspects contribute to the effectiveness of the author's act of communication. 
- How inventively does the author fulfil the requirements of the situation?

- How ethical are the author's means of persuasion as well as his appeals to the readers' emotions, and his use of language?

- What will be the cost of participation for the readers? As the power of a text depends on the reader's willingness to participate in the communication process, it is important to determine how much inconvenience and discomfort are involved, how much time, energy and commitment are needed, how much of the reader's resources, money, and expertise must be expended, and how much social resistance can be expected from family, friends and neighbours (see Campbell, 1982:106-109).

- What is the potential power of the text to change beliefs, attitudes and actions?

In order to answer the above questions a rhetorical analysis consisting of the following elements is needed:

- the nature of the text (in the case of the New Testament we are confronted by "sacred" texts e.g. which will ask more commitment from the readers);

- the structure, argument, pattern of the arguments, persuasion strategies and style (in order to determine the clarity e.g. of the text and the author's creativity);

- the value system presented in the text (to determine the clarity of the text);

- social and cultural topoi (to determine whether the relevant aspects are provided);

- the purpose of the text (to determine whether the purpose of the text has been reached, we at least need to know what the purpose of the text is);

- the characteristics of the author, his/her role, social power, relationship with the readers, value system, issue orientation, and communication (to determine e.g. whether the readers will be willing the accept the author's presentation of himself);

- the readers' characteristics, their receptivity to the rhetorical act and topoi, their circumstances, their knowledge and faith presupposed by the author, their value system, and the cost of participation (to 
determine whether the readers can recognize themselves in the author's presentation of the ideal readers).

A method for rhetorical criticism will be a holistic approach and will involve a close reading of the text in which different methods may play a role. The text will also be approached from a socio-historical perspective for the interpretation of typical ancient communication strategies, typical ancient topoi, ancient epistolary structures, ancient values, and roles in ancient society and the ancient church.

\section{Conclusion}

It was argued that rhetorical criticism is becoming more and more recognized as a method of interpretation of biblical literature. From the discussion it became clear that there are different perspectives of rhetorical criticism just as there are different theories of rhetoric. There are, however, serious problems concerning rhetorical criticism. Rhetorical criticism, understood as interpretation and evaluation, remains a vague concept. Rhetoric has been restricted, distorted and paralysed throughout history. Critics need to develop an interdisciplinary method of rhetorical criticism in order to answer questions about the potential effectiveness of a rhetorical act. It is concluded that the rhetorical critic needs a combination of "old" methods in order to answer new questions.

\section{Bibliography}

ANDREWS, J.R. 1990. The practice of rhetorical criticism. London : Collier Macmillan Publishers.

ARISTOTLE. Ars Rhetorica. London : William Heinemann. (Loeb Classical Library.) 1947.

BERGER, K. 1974. Apostelbrief und apostolische Rede: Zum Formular fruhchristlichen Briefe. Zeitschrift fur die Neutestamentliche Wissenschaft und die Kunde der Alteren Kirche, 65:190-231.

BETTINGHAUS, E.P. \& CODY, M.J. 1994. Persuasive communication. New York : Harcourt Brace Jovanovich College Publishers.

BETZ, H.D. 1975. The literary composition and function of Paul's letter to the Galatians. New Testament Studies, 21:353-379.

BLACK, C.CII. 1989. Keeping up with recent studies. xvi. Rhetorical criticism and Biblical interpretation. The Expository Times, 100:252-258.

BOTHA, J. 1994. Subject to whose authority? Multiple readings of Romans 13. Atlanta : Scholars Press. (Emory Studies in Early Christianity, Editor Vernon K. Robbins.)

BRINTON, A. 1981. Situation in the theory of rhetoric. Philosophy and Rhetoric, 14:234-248.

BROCK, B.L., SCOTT, L. \& CHESEBRO, J.W. 1990. Methods of rhetorical criticism. A twentieth-century perspective. Third edition, revised. Detroit : Wayne State University.

BURKE, K. 1950. A rhetoric of motives. Englewood Cliffs, New Jersey : Prentice-Hall. CAMPBELL, K.K. 1982. The rhetorical act. California : Wadsworth. 
COHEN, D. 1994. Classical rhetoric and modern theories of discourse. (In Worthington, I., ed. Persuasion. Greek rhetoric in action. London : Routledge. p. 69-82.)

CORNELIUS, E.M. 1991. Die funksie van die danksegging(s) in 1 Tessalonisense. Potchefstroom : PU for CHE. (M.A. dissertation.)

CROFT, A.J. 1965. The functions of rhetorical criticism. (In Schwartz, J. \& Rycenga, J.A., eds. The province of rhetoric. New York : Ronald Press Company. p. 403414.)

FOSS, S.K. 1989. Rhetorical criticism. Exploration and practice. Illinois : Waveland.

HOCHMUTH NICHOLS, M. 1971a. Kenneth Burke and the "New Rhetoric". (In Johannesen, R.L., ed. Contemporary theories of rhetoric: Selected readings. New York: Harper \& Row. p. 96-116.)

HOCHMUTH NICHOLS, M. 1971b. I.A. Richards and the "new rhetoric". (In Johannesen, R.L., ed. Contemporary theories of rhetoric: Selected readings. New York : Harper \& Row. p. 127-147.)

HUGHES, F.W. 1989. Early Christian rhetoric and 2 Thessalonians. Sheffield : JSOT Press.

JOHANNESEN, R.L., ed. 1971. Contemporary theories of rhetoric: Selected readings. New York : Harper \& Row Publishers.

JOHANSON, B.C. 1987. To all the brethren. A text-linguistic and rhetorical approach to I Thessalonians. Stockholm : Almqvist \& Wiksell International. (Coniectanea Biblica New 15 Testament Series, 16.)

KAEL, P. 1964. I lost it at the movies. Boston : Little \& Brown.

KENNEDY, G.A. 1984. New Testament interpretation through rhetorical criticism. Chapel Hill, North Carolina : University of North Carolina.

KENNEDY, G.A. 1992. A hoot in the dark: The evolution of general rhetoric. Philosophy and Rhetoric, 25(1):1-21.

KESSLER, M. 1982. A methodological setting for rhetorical criticism. (In Cline, D.J.A., Gunn, D.M. \& Hauser, A.J., eds. Art and meaning: Rhetoric in Biblical literature. Sheffield: Sheffield Academy. p. 1-19.)

KIKAWADA, I.M. 1977. Some proposals for the definition of rhetorical criticism. Semitics, 5:67-91.

KRAFTCHICK, S.J. 1985. Ethos and pathos appeals in Galatians five and six: a rhetorical analysis. Emory : Emory University. (Ph.D. thesis.)

LARSON, C.U. 1998. Persuasion. Reception and responsibility. London : Wadsworth. MACK, B.L. 1990. Rhetoric and the New Testament. Minneapolis : Fortress Press.

MILLER, G.R., BURGOON, M. \& BURGOON, J.K. 1984. The functions of human communication in changing attitudes and gaining compliance. (In Arnold, C.C. \& Bowers, J.W., ed. Handbook of rhetorical and communication theory. Boston : Allyn \& Bacon. p. 400-474.)

MUILENBURG, J. 1969. Form criticism and beyond. Journal of Biblical Literature, 88: 1-18.

MURPHY, J.J. 1974. Rhetoric in the Middle Ages. A history of rhetorical theory from Saint Augustine to the Renaissance. London : University of California Press.

OHMANN, R. 1971. In lieu of a new rhetoric. (In Johannesen, R.L., ed. Contemporary theories of rhetoric: Selected readings. New York : Harper \& Row Publishers. p. 63-74.)

PERELMAN, C. \& OLBRECHTS-TYTECA, L. 1969. The new rhetoric. A treatise on argumentation. Notre Dame : University of Notre Dame Press.

PERELMAN, C.H. 1982. The realm of rhetoric. Trans. W Kluback. London : University of Notre Dame Press. 
QUINTILIAN Institutio Oratoria. Volumes I-IV. London : William Heinemann. (Loeb Classical Library.) 1947.

RICHARDS, I.A. 1954. Practical criticism. New York : Harcourt, Brace \& World.

ROBBINS, V.K. 1996a. The tapestry of early Christian discourse. Rhetoric, society and ideology. New York : Routledge.

ROBBINS, V.K. 1996b. Exploring the texture of texts. A guide to socio-rhetorical interpretation. Valley Forge, Pennsylvania : Trinity Press International.

SCHUSSLER FIORENZA, E. 1987. Rhetorical situation and historical reconstruction in I Corinthians. New Testament Studies, 33:386-403.

SCOTT, R.L. \& BROCK, B.L. 1972. Methods of rhetorical criticism. New York : Harper \& Row.

SIMONS, H.W. 1971. Toward a new rhetoric. (In Johannesen, R.L., ed. Contemporary theories of rhetoric. Selected Readings. New York : Harper \& Row. p. 50-62.)

STOWERS, S.K. 1986. Letter writing in Greco-Roman antiquity. Philadelphia : Westminster.

THONSSEN, L., BAIRD, A.C. \& BRADEN, W.W. 1970. Speech criticism. Second Edition. New York : The Ronald Press Company.

THUREN, L. 1990. The rhetorical strategy of 1 Peter. With special regard to ambiguous expressions. Abo : Abo Academy Press.

VAN EEMEREN, F.H., GROOTENDORST, R. \& KRUIGER, T. 1987. Handbook of argumentation theory: A critical survey of classical backgrounds and modern studies. Dordrecht : Pragmatics and Discourse Analysis.

VORSTER, J.N. 1991. The rhetorical situation of the letter to the Romans - an interactional approach. Pretoria : University of Pretoria. (D.D. thesis.)

WATSON, D.F. \& HAUSER, A.J. 1994. Rhetorical criticism of the Bible. A comprehensive bibliography with notes on history and method. New York : Brill.

WHITE, J.L. 1972. The form and function of the body of the Greek letter. A study of the letter-body in the non-literary papyri and in Paul the apostle. Montana : Scholars Press. (Society of Biblical Literature, Dissertation Series, 2.)

WINTEROWD, W.R. 1968: Rhetoric: a synthesis. London : Holt, Rinehart and Winston.

WUELLNER, W. 1976. Paul's rhetoric of argumentation in Romans: An alternative to the Donfried-Karris debate over Romans. Catholic Bible Quarterly, 38:330-351.

WUELLNER, W. 1987. Where is rhetorical criticism taking us? Catholic Bible Quarterly, 49(1987)448-463.

WUELLNER, W. 1995. Rhetorical criticism. (In Castelli, E.A., Moore, S.D., Phillips, G.A. \& Schwartz, R.M., eds. The Postmodern Bible. New Haven : Yale University Press. p. 149-186.)

\section{Key concepts:}

hermeneutics, of the new Testament

rhetoric

rhetorical criticism

\section{Kernbegrippe:}

hermeneuse, van die Nuwe Testament

retoriek

retoriese kritiek 